\title{
NATIONAL PHYSICAL LABORATORY RADIOCARBON MEASUREMENTS IV
}

\author{
IV. J. GALLOW, M. J. BAKER and GERALDINE I. HASSALL \\ National Physical Laboratory, Teddington, England
}

The following list comprises measurements made since those reported in NPL III and is complete to the end of November 1965.

Ages are relative to A.D. 1950 and are calculated using a half-life of $5568 \mathrm{yr}$. The measurements, corrected for fractionation (quoted $\delta \mathrm{C}^{13}$ values are relative to the P.D.B. standard), are referred to 0.950 times the activity of the NBS oxalic acid as contemporary reference standard. The quoted uncertainty is one standard deviation derived from a proper combination of the parameter variances as described in detail in NPL III. These variances are those of the standard and background measurements over a rolling twenty week period, of the sample $\delta \mathrm{C}^{14}$ and $\delta \mathrm{C}^{13}$ measurements and of the de Vries effect (assumed to add an additional uncertainty equivalent to a standard deviation of $80 \mathrm{yr}$ ). Any uncertainty in the half-life has been excluded so that relative $\mathrm{C}^{14}$ ages may be correctly compared. Absolute age assessments, however, should be made using the accepted best value for the half-life and the appropriate uncertainty then included. If the net sample count rate is less than 4 times the standard error of the difference between the sample and background count rates, a lower limit to the age is reported corresponding to a net sample count rate of 4 times the standard error of this difference.

The description of each sample is based on information provided by the person submitting the sample to the laboratory.

The work reported forms part of the research program of the $\mathrm{Na}$ tional Physical Laboratory and is published by permission of the Director of the Laboratory.

I. ARCHAEOLOGIC AND GEOLOGIC SAMPLES

\section{A. England}

\section{NPL-104. Cow Down 1. Wiltshire}

$$
2480 \pm 90
$$

Wood charcoal (Q. robur) from post hole, probably from post itself, of house of Late Bronze Age or very Early Iron Age at Cow Down $\left(51^{\circ} 10^{\prime} \mathrm{N}\right.$ Lat, $2^{\circ} 10^{\prime} \mathrm{W}$ Long), Longbridge Deverhill, nr. Warminster, Wiltshire. Coll. 1958-60 by S. Hawkes; subm. by L. Biek, Ministry of Public Bldg. and Works. Comment (L.B.): although the associated pottery has remarkable affinities to French Bronze Age types of 8 th-7th century B.c., result in fact confirms excavators' estimate of time occupation of this house. $\delta \mathrm{C}^{13}=-25.0 \%$.

$8570+1850$

NPL-72. Mockerkin Tarn, West Cumberland

6620 B.C.

Wood fragment (probably Betula pubescens) from pollen zone 
boundary VIIa/b of lake deposit, $270 \mathrm{~cm}$ below mud surface, Mockerkin Tarn (54 $35^{\prime} \mathrm{N}$ Lat, $3^{\circ} 25^{\prime} \mathrm{W}$ Long), West Cumberland. Coll. 1963 and subm. by W. Tutin, Univ. of Leicester. Comment (W.T.): result is more than $3000 \mathrm{yr}$ greater than expected from sample position in profile. This discourages use of fragments of allochthonous organic matter as dating material (Clark and Godwin, 1962).

\section{NPL-86. Teignmouth, Devonshire}

$$
\begin{aligned}
& 8580+830 \\
& 6630 \text { B.c. }
\end{aligned}
$$

Peat from layer $5 \mathrm{~cm}$ thick underlying $74 \mathrm{~cm}$ of estuarine clay and $100 \mathrm{~cm}$ of sand off English Channel seaboard near Teignmouth $\left(50^{\circ} 31^{\prime}\right.$ $30^{\prime \prime} \mathrm{N}$ Lat, $3^{\circ} 25^{\prime} 00^{\prime \prime} \mathrm{W}$ Long), Devonshire, England. Coll 1964 and subm. by R. H. Clarke, Univ. of Bristol. Comment (R.H.C.): pollen analyses place sample at beginning of Zone VIa which with this $\mathrm{C}^{14}$ measurement substantiates assignment of Late Glacial-Postglacial (Flandrian) age to these submerged estuarine deposits. Sample lies approx. $-78 \mathrm{ft}$ O.D. and apparently underlain by a (terrestrial) soil, thus appearing to represent onset of brackish water at that point. Present tidal range at Teignmouth is $12.7 \mathrm{ft}$ (Springs), so mean sealevel at that time was therefore approx. $85 \mathrm{ft}$. This agrees well with published information on Postglacial eustatic rise in sealevel (Godwin et al, 1958).

\section{NPL-87. Brandon Terrace, Warwickshire $\quad \mathbf{2 8 , 2 0 0} \pm \mathbf{5 0 0}$}

Twigs and leaves (B. nana) washed from vegetable debris in thin peat layer underlying 13-ft thick gravel deposit of Avon No. 2 terrace at Brandon $\left(52^{\circ} 22^{\prime} 30^{\prime \prime} \mathrm{N}\right.$ Lat, $1^{\circ} 26^{\prime} 00^{\prime \prime} \mathrm{W}$ Long), Warwickshire. Coll. 1964 and subm. by F. W. Shotton, Univ. of Birmingham. Comment (F.W.S.): sample was rolled mass from channel of peaty silts under $12 \mathrm{ft}$ gravel belonging to Avon No. 2 river terrace. Insect fauna indicates cold conditions, and a peat with similar fauna and in same basal position from same terrace at Fladbury (Worcs.) gave age of 38,000 \pm 700 (GRO1269). Brandon sample is therefore younger than expected but this might be result of a long period of alluviation progressively upstream.
$\delta \mathrm{C}^{13}=-25.0 \%$.

NPL-88. Austerfield, Yorkshire

Wood fragments from peaty layer at depth of $6 \mathrm{ft} 6$ in. at Austerfield gravel pit ( $53^{\circ} 27^{\prime} 22^{\prime \prime} \mathrm{N}$ Lat, $0^{\circ} 59^{\prime} 47^{\prime \prime} \mathrm{W}$ Long), Yorkshire. Coll. 1964 and subm. by G. D. Gaunt, Geol. Surv. \& Mus. Comment: it was hoped that measurement would provide useful information on which to base mapping of Humber basin deposits, hitherto estimated as Fluvioglacial. $\delta \mathrm{C}^{13}=-25.0 \%$.

\section{NPL-99. Isleworth 2 Middlesex}

Stem fragments in silt at base of gravels comprising a low terrace of the Thames at Isleworth ( $51^{\circ} 27^{\prime} 30^{\prime \prime} \mathrm{N}$ Lat, $0^{\circ} 20^{\prime} 00^{\prime \prime} \mathrm{W}$ Long), Mid- 
dlesex. Coll. 1959 and subm. by F. W. Shotton, Univ. of Birmingham. Comment: sample derived from deposit of organic silt underlying sands and gravels which produced numerous bones of bison and reindeer. Structure of gravels and enclosed fauna indicated cold conditions. Stratigraphy of gravels indicated that they were deposited at some time during Last (Weichselian or Würm) Glaciation. Insects from plant beds indicate temperate conditions and may thus have lived either during Last (Eemian) Interglacial or an interstadial in Last Glaciation (NPL-34, NPL II) $\cdot \delta \mathrm{C}^{13}=-25.0 \%$.

\section{Romney Marsh series, Kent}

Samples from clay and peat deposits at Scotney Court Farm $\left(50^{\circ}\right.$ $57^{\prime}$ N Lat, $00^{\circ} 54^{\prime}$ E Long), Lydd, Romney Marsh, Kent. Coll. 1964 and subm. by R. D. Green, Rothamsted Expt. Stn. Comment: NPL-91 establishes latest possible date for development of older parts of shingle beach complex of Dungeness. Roots of NPL-92 were clearly in situ and were certainly present before overlying clay sediments were deposited. Result suggests roots to be approx. contemporary with peat elsewhere in Romney Marsh (NPL-23, NPL II) and, with age of NPL-91, implies this thin peat not to be sedimentary but all in situ. Thus associated shingle ridges may not be "the shore formed when sealevel rose to near the present and drowned the $25 \mathrm{ft}$ submerged forest", as previously suggested (Lewis and Balchin, 1940).

\section{NPL-91. Scotney Court Farm 1}

$2050 \pm 90$

Peat from layer 2 in. thick, at depth of 48 in. overlying clay deposit with roots (NPL-92). $\delta \mathrm{C}^{13}=-27.0 \%$.

\section{NPL-92. Scotney Court Farm 2}

$2740 \pm 400$

Roots from clay deposit, 30 in. thick, at depth of 50 in. underlying thin peat layer (NPL-91).

\section{Channel Borehole series}

Drift deposits from Channel Tunnel Site Investigation borehole P.040 (P3) $\left(51^{\circ} 06^{\prime} 04^{\prime \prime} \mathrm{N}\right.$ Lat, $01^{\circ} 24^{\prime} 08^{\prime \prime}$ E Long), beneath sea bed $-34.7 \mathrm{~m}$ N.G.F. (-113 ft O.D.) occupying shallow sinuous valley on submerged dip slope of Middle Chalk (Turonian) inclined gently to NNE. Coll. 1964 by Wimpey; subm. by E. R. Shephard-Thorn, Geol. Survey and Mus. Comment (E.R.S.T.): date for NPL-103 falls in pollen Zone III, that for NPL-101 in Zone IV, implying deposits to span conventionally accepted Late Glacial-Holocene boundary. Palynological evidence confirms this conclusion. In both samples tree pollen is dominated by pine and birch, but NPL-103 has higher proportion of herbaceous pollen; neither sample contains evidence of marine or estuarine deposition. Age and depth of deposits confirm that they predate Lower 
Peat of the Netherlands (Jelgersma, 1961), and that there has since been a minimum relative sealevel rise of $120 \mathrm{ft}$; they also indicate their comparability with deeper moorlogs of North Sea (Godwin 1943, 1945, 1960).

NPL-101. Borehole P3 Sample A sea bed surface. $\delta \mathrm{C}^{13}=25.0 \%$.

NPL-103. Borehole P3 Sample B

$$
\begin{gathered}
10,530 \pm 120 \\
8580 \text { в.C. }
\end{gathered}
$$

Peat clay from layer $3 \mathrm{ft}$ thick immediately underlying NPL-101. $\delta \mathrm{C}^{13}=-25.0 \%$.

\section{Scottish Highland series}

$$
\text { B. Scotland }
$$

This series of samples from east-central Highlands represents sites of both hill (NPL-94, 95) and basin (NPL-96, 111, 112) peat formation. Results support current view, suggested from palynological data, that the latter were first to begin formation (Synge, 1956). All samples coll. 1964 and subm. by J. M. Stewart, Macaulay Inst. for Soil Res.

NPL-94. Cruden 1 Aberdeenshire
Amorphous peat from organic-mineral interphase at depth of 125 $\mathrm{cm}, 450 \mathrm{ft}$ O.D. at Cruden ( $57^{\circ} 27^{\prime} 12^{\prime \prime} \mathrm{N}$ Lat, $1^{\circ} 57^{\prime} 6^{\prime \prime} \mathrm{W}$ Long), Aberdeenshire Scotland. $\delta \mathrm{C}^{13}=-25.0 \%$.

\section{NPL-95. Cairn o Mount, Kincardinshire}

$4040 \pm 95$ cm, 1470 ft O.D. $\mathrm{cm}, 1470 \mathrm{ft}$ O.D. at Cairn a Mount $\left(56^{\circ} 55^{\prime} \mathrm{N}\right.$ Lat, $2^{\circ} 34^{\prime} \mathrm{W}$ Long), Kincardinshire, Scotland. $\delta \mathrm{C}^{13}=-21.0 \%$.

\section{NPL-96. Slack Burn, Kincardinshire \\ $7220 \pm 235$ \\ 5270 B.c.}

Amorphous peat from organic-mineral interphase at depth of 810 $\mathrm{cm}, 1400 \mathrm{ft}$ O.D. at Slack Burn (56 $56^{\prime} 30^{\prime \prime} \mathrm{N}$ Lat, $2^{\circ} 33^{\prime} 0^{\prime \prime} \mathrm{W}$ Long), Kincardinshire, Scotland. $38 \mathrm{C}^{13}=-22.3 \%$.

NPL-111. Candyglirach, Aberdeenshire
Amorphous peat from organic-mineral interphase at depth of 505

$9000 \pm 135$ $\mathrm{cm}, 250$ to $275 \mathrm{ft}$ O.D. at Candyglirach $\left(57^{\circ} 06^{\prime} 12^{\prime \prime} \mathrm{N}\right.$ Lat, $02^{\circ} 25^{\prime} 00^{\prime \prime}$ $\mathrm{W}$ Long). Aberdeenshire, Scotland. $\delta \mathrm{C}^{13}=-27.0 \%$.

\section{NPL-112. Cruden 2 Aberdeenshire}

$5580 \pm 100$

Amorphous peat from oronic-mineral interpha cm, 350 to $400 \mathrm{ft}$ O.D. at Cruth of 206 Long), Aberdeenshire, Scotland. $\delta \mathrm{C}^{13}=-30.4 \%$. 


\section{Wales}

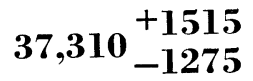

NPL-97. Tre-Llys, North Pembrokeshire

Marine shell from gravel pit at Tre-Llys $\left(51^{\circ} 57^{\prime} 45^{\prime \prime} \mathrm{N}\right.$ Lat, $5^{\circ} 4^{\prime}$ $25^{\prime \prime}$ W Long), nr. St. Nicholas, Fishguard, North Pembrokeshire, $200 \mathrm{ft}$ O.D. Coll. 1964 and subm. by B. S. John, Univ. of Oxford. Comment (B.S.J.): this date and NPL-80 $(37,960+1700$, NPL III) relate to outwash gravels laid down during melting of last Irish Sea ice sheet and indicate that gravels of so-called "South Wales End-moraine" of N Pembrokeshire are no younger than glacial deposits found $18 \mathrm{mi}$ further $\mathrm{S}$. Evidence suggests that interstadial boreal conditions persisted in Irish Sea 38,000 yr B.P. and that Last Glaciation of W Wales followed this interstadial phase, possibly as equivalent of European Main Würm glaciation (John, 1965; West, 1963; Mitchell, 1960; Zeuner, 1959; Charlesworth, 1929). $\delta \mathrm{C}^{13}=-8.2 \%$.

NPL-98. Aber-Mawr, North Pembrokeshire

Wood (probably Pinus sp) from calcareous boulder clay at AberMawr (51 $57^{\prime} 40^{\prime \prime} \mathrm{N}$ Lat, $5^{\circ} 5^{\prime} 30^{\prime \prime} \mathrm{W}$ Long), nr. St. Nicholas, Fishguard, N Pembrokeshire. Coll. 1964 and subm. by B. S. John, Univ. of Oxford. Comment (B.S.J.): stratigraphic evidence suggests that this Irish Sea till is no older than shelly outwash at Mullock Bridge (NPL-80 $37,960+1700$, NPL III) and Tre-1lys (NPL-97) (Mitchell, 1960; Synge, 1961; Synge and Stevens, 1960; West, 1963; John, 1965).

\section{Canada}

\section{NPL-82. R. aux-Roches Valley, Quebec}

$6760 \pm 140$

4810 B.c.

Shell (Mya truncata and Hiatella arctica) from side of A2 terrace at $148 \mathrm{ft}$ O.D. in $\mathrm{N}$ bank R. aux-Roches Valley $\left(62^{\circ} 02^{\prime} \mathrm{N}\right.$ Lat, $74^{\circ} 32^{\prime}$ W Long), near Deception Bay, Quebec, Canada. Coll. 1962 and subm. by Barry Matthews, McGill Univ. Comment (B.M.): as sample was obtained from the only marine deposit found $8 \mathrm{mi}$ inland from Deception Bay, date suggests a valley glacier prevented incursion of sea into $R$. aux-Roches valley until well into "postglacial" times. $\delta \mathrm{C}^{13}=-6.8 \%$.

\section{NPL-83. R. Renard-Noir Valley, Quebec}

Marine shell (Hiatella arctica, Mya truncata, Balanus balanus, Clinocardium ciliatum) from silt polygons immediately below scarp of $237 / 248$ $\mathrm{ft}$ raised beach remnant, $\mathrm{N}$ side of $\mathrm{R}$. Renard-Noir Valley $\left(62^{\circ} 07^{\prime} \mathrm{N}\right.$ Lat, $74^{\circ} 38^{\prime}$ W Long), Deception Bay, Quebec, Canada. Coll. 1962 and subm. by Barry Matthews. $\delta \mathrm{C}^{13}=-5.2 \%$. 


\section{NPL-84. R. Renard-Noir Valley, Quebec}

$6660 \pm 130$

Macoma calcarea), (Hiatella arcica, Mya truncata, Macoma balthica, Valley $\left(69^{\circ} 07^{\prime}\right)$ from $242 \mathrm{ft}$ raised beach, S side of R. Renard-Noir ( $07^{\prime} \mathrm{N}$ Lat, $74^{\circ} 38^{\prime} \mathrm{W}$ Long), Deception Bay, Quebec, Canada. Coll. 1962 and subm. by Barry Matthews. Comment (B.M.) : despite difference of $47 \mathrm{ft}$ in altitude and differing percentages of various mollusc species, deposits represented by NPL-83 and this sample appear to have formed at about same time but probably in different depths of water. Comparative richness of marine fauna in $242 \mathrm{ft}$ deposit might indicate a warming of sea at ca. $6700 \mathrm{yr}$ ago during early part of Hypsithermal Interval. $\delta \mathrm{C}^{13}=-5.1 \%$.

\section{NPL-85. R. Renard-Noir Valley, Quebec}

$6970 \pm 125$

Marine shell (Hiatella arctica, Balanus sp.) from sandy clay near surlace of $297 \mathrm{ft}$ raised beach, N side R. Renard-Noir Valley $\left(62^{\circ} 07^{\prime} \mathrm{N}\right.$ Lat, $74^{\circ} 38^{\prime}$ W Long), Deception Bay, Quebec, Canada. Coll. 1962 and subm. by Barry Matthews. Comment (B.M.): although age is much younger than expected in view of previous determination of $10,450 \pm 250$ B.P. (I-488, Isotopes, Inc., unpub.) obtained from same raised beach, it is similar to other $\mathrm{C}^{14}$ dates (I-729, I-726, Isotopes, Inc., unpub.) of material from near post-glacial marine limit in northern Ungava. Considerable doubt is now cast on theory that Hudson Strait was free from ice during classical Wisconsin Maximum (Ives, 1963) or even 10,500 yr ago. It is also doubtful if E-W warping of raised marine beaches below $300 \mathrm{ft}$ O.D. occurred during postglacial isostatic uplift since shells from a raised marine beach at a similar elevation but $100 \mathrm{mi}$ to $\mathrm{W}$ at Wolstenholme are of comparable age, i.e. $6900 \pm 130$ yr B.P. (NPL-58, NPL III) (Matthews, 1964, 1963, 1962; Farrand and Gadja, 1962). $\delta \mathrm{C}^{13}=-1.9 \%$.

\section{E. Egypt}

NPL-5. Tarkhan, interlaboratory check

$4310 \pm 90$

Linen from lst Dynasty mastaba (2050) at Tarkhan $\left(29^{\circ} 40^{\prime} \mathrm{N}\right.$ Lat, $31^{\circ} 13^{\prime}$ E Long), near Cairo, Egypt. Material from W. M. Flinders Petrie Colln., Univ. College of London, is securely dated to Wadji, fourth king of this dynasty. Sample was measured at UCLA-739, $4265 \pm$ 80, UCLA IV; descr. by Flinders Petrie (1914). $\delta \mathrm{C}^{13}=-25.0 \%$.

II. ATMOSPHERIC $\mathrm{CO}_{2}$ MEASUREMENTS
NPL-90. Sizewell, Suffolk
$\delta \mathbf{C}^{14 \%} \%$
$907 \pm 13-12.0 \pm 1 \quad 857 \pm 13$
Atmospheric $\mathrm{CO}_{2}$ from Sizewell $\left(52^{\circ} 12^{\prime} 30^{\prime \prime} \mathrm{N}\right.$ Lat, $1^{\circ} 34^{\prime} 00^{\prime \prime} \mathrm{W}$ Long), Suffolk. Coll. July to October 1964 by F. E. Bentley; subm. by B. C. Godbold, Esq. 


\section{NPL-100. Berkeley, $\quad \delta \mathbf{C}^{14 \%} \% 0 \quad \delta \mathbf{C}^{13 \%} \%$ \\ $\begin{array}{llll}\text { Gloucestershire } & 882 \pm 17 & -11.8 \pm 1 & 832 \pm 17\end{array}$}

Atmospheric $\mathrm{CO}_{2}$ from Berkeley ( $51^{\circ} 41^{\prime} \mathrm{N}$ Lat, $2^{\circ} 28^{\prime} \mathrm{W}$ Long), Gloucestershire. Coll. Autumn 1964 by K. E. White; subm. by B. C. Godbold, Esq.

\section{REFERENCE MEASUREMENT}

NPL-3. Heidelberg Sodium Carbonate Standard $\quad 10.224=0.033$

Labeled sample H-522 distributed by K. O. Munnich. Result given is ratio of activity of this sample to $95 \%$ of oxalic acid standard. $\delta \mathrm{C}^{13}=-9.8 \%$.

Date lists:

\section{REFERENCES}

UCLA IV Berger, Fergusson and Libby, 1965

NPL II Callow, Baker and Pritchard, 1964

NPL III Callow, Baker and Hassall, 1965

Berger, R., Fergusson, G. J., Libby, W. F., UCLA radiocarbon dates IV': Ratliocarbon, v. 7 , p. $336-371$.

Callow, W. J., Baker, M. J., and Pritchard, D. H., 1964, National Physsical Laboratory radiocarbon measurements II: Radiocarbon, v. 6, p. 25-30.

Callow, W. J., Baker, M. J., and Hassall, G. I., 1965, National Phỵsical Laboratory radiocarbon measurements III: Radiocarbon, v. 7, p. 156-161.

Charlesworth, J. K., 1929, The South Wales End-Moraine: Q.J.G.S., r. 85, p. 335-358.

Clark, J. G. D., and Godwin, H., 1962, The Neolithic in the Cambridgeshire Fens: Antiquity, v. 36 , no. 141 , p. 10-23.

Farrand, W. R., and Gadja, R. T., 1962, Isobases on the Wisconsin Marine Limit in Canada: Geol. Bull. 17, Canadian Dept. of Mines and Technical Surveys.

Godwin, H., 1943, Coastal peat beds of the British Isles and North Sea: Jour. Ecology, v. 31 , no. 2, p. 199-247.

1945, Coastal peat beds of the North Sea region as indices of land and sea level changes: New Phytologist, v. 44, p. 29-65.

Godwin, H., Suggate, R. P., and Willis, E. H., 1958 Radiocarbon dating of the eustatic rise in ocean-level: Nature, v. 181, p. 1518-1519.

Green, R. D., and Askew, P. W., 1959, Report Soil Survey Research Board No. 11, p. 22.

Ives, J. D., 1963, Field problems in determining the maximum extent of Pleistocene Glaciation along the Eastern Canadian Seaboard-a geographer's point of riew; in North Atlantic Biota and their History, ed. A. and D. Löve: Pergamon Press, Oxford.

Jelgersma, S., 1961, Holocene sea level changes in the Netherlands: Meded. Geol. Sticht, serie C. VI, no. 7, p. 9-85.

John, B. S., 1965, A possible Main Würm glaciation in West Pembrokeshire: Nature, v. 207 , no. 4997 , p. $622-623$.

Lewis, W. V., and Balchin, W. G. V., 1940, Past sea levels at Dungeness: Geog. Journal, v. 96, p. 258-285.

Matthews, B., 1962, Glacial and post-glacial geomorphology of the Suglok-Wolstenholme area. Northern Ungava: McGill Sub-Arctic Research Papers, no. 12.

1963, Glacial geomorphological investigations in Northern Ungava, Quebec, Canada: Ice, no. 12, p. 9-10.

1964, The Late-Pleistocene glaciation and deglaciation of Northernmost Ungava, Quebec: Unpub. reports presented to the Arctic Inst. of North America, Washington Office, p. 94. 
National Physical Laboratory Radiocarbon Measurements IV 347

Mitchell, G. F., 1960, The Pleistocene History of the Irish Sea: Adv. Sci., v. 17, p. $313-325$.

Petrie, W. M. Flinders, 1914, Tarkhan II: British School of Archeol. in Egypt (London), p. 6.

Synge, F. M., 1956, Glaciation of North East Scotland: The Scottish Geog. Mag., v. 72 , no. 3 , p. 129-143.

W. 1961, A correlation between the drift of S. E. Ireland and those of W. Wales: Report No. 2, Welsh Soils discussion group, Aberystwyth.

Synge, F. M., and Stevens, N., 1960, The Quaternary Period in Ireland-an assessment: Irish Geog., v. 4, p. 121-130.

West, R. G., 1963, Problems of the British Quaternary: Proc. Geol. Assoc., v. 74, no. 2, p. 147-186.

Zeuner, F. E., 1959, The Pleistocene Period: Hutchingson, London, p. 145. 